
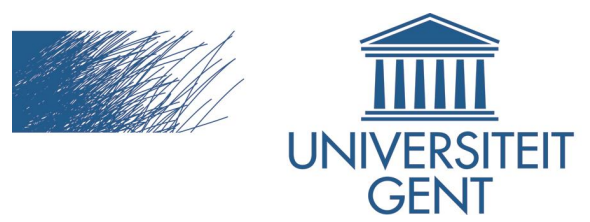

biblio.ugent.be

The UGent Institutional Repository is the electronic archiving and dissemination platform for all UGent research publications. Ghent University has implemented a mandate stipulating that all academic publications of UGent researchers should be deposited and archived in this repository. Except for items where current copyright restrictions apply, these papers are available in Open Access.

This item is the archived peer-reviewed author-version of:

Ernst Grosse and the "Ethnological Method" in Art Theory

Wilfried van Damme

In: Philosophy and Literature 34 (2), pp. 302-312, 2011

To refer to or to cite this work, please use the citation to the published version:

Wilfried van Damme (2010). Ernst Grosse and the "Ethnological Method" in Art Theory. Philosophy and Literature (34/2): 302-312. DOI 10.1353/phl.2010.0003

\title{
Ernst Grosse and the "Ethnological Method" in Art Theory
}

\author{
Wilfried van Damme
}

Abstract: Intercultural and interdisciplinary approaches are today rightfully heralded as the most promising ways forward in the theoretical study of art and aesthetics. But that does not mean such approaches have not been considered before. In the late nineteenth century, the philosopher Ernst Grosse did just that, encapsulating his proposals in what he called the "ethnological method." Moreover, he identified a series of predecessors who had either applied a cross-cultural perspective or drawn on various disciplines in examining art and aesthetics. This paper brings to light a 
forgotten but surprisingly "modern" tradition of art theoretical thought.

Why are the Germans good at music, whereas the Dutch excel in painting? What are the reasons for the outstanding draftsmanship of Australian Aboriginals, and why does this skill seem absent among West African peoples, who appear concerned rather with sculpture? Could it be that the Japanese do not share the European preference for symmetry in decorative art? Moreover, why do tastes in the visual arts, music, and literature change so noticeably throughout history? Is it possible that, despite differences across time and space, there are features that each of humanity's arts share?

These are some of the questions that in the late nineteenth century were going through the mind of the German scholar Ernst Grosse (1862-1927). Trained as a philosopher, but influenced by the new natural sciences of his day, Grosse thought it possible to develop an approach that would answer such questions in a scientific manner. Key to his approach was the burgeoning field of ethnology. Ethnology would provide not only a method for tackling such questions but the empirical data on which the answers to these questions needed to be based. By drawing on ethnology, art theory would be able to transcend its eurocentric bias, abandon its speculative character, and get closer to the spirit of the natural sciences.

Grosse outlined his views in an 1891 essay titled "Ethnologie und Aesthetik."*1 The first part of this essay he devotes to a survey of previous attempts to have ethnology shine its light on questions in art theory. Leading him back to the early eighteenth century, this historical outline serves at the same time to introduce Grosse's own views. The relevance of these views he then discusses in the context of the experimental aesthetics that was being developed in his own time.

Grosse's analysis draws attention to what I assert are overlooked ways of framing the study of art and aesthetics. The theoretical positions they propound are worth reconsidering for several reasons. For one, the eighteenth- and nineteenth-century views discussed below merit attention for 
their own sake, as developments in the history of European thought in the arts and humanities. An acquaintance with these views, moreover, may invite one to reconsider historiographic accounts of such fields as the philosophy of art, empirical aesthetics, and especially the anthropology of art and aesthetics. The disciplinary history of this last field now usually starts with late-nineteenth-century evolutionistic studies of ornament, or even as late as with the publication of Franz Boas's book Primitive Art in 1927.*2 Finally, what follows offers a historical overview of proposals for a global and interdisciplinary study of art and aesthetics at a time when an increasing number of scholars are again making such proposals. $* 3$

Grosse begins by observing that ethnology has by now clearly proven its value to the humanities (Geisteswissenschaft). In whatever field they have been deployed (be it ethics, political science, or religious studies), the "treasures of ethnology" have so much enriched our knowledge and led to such a transformation of views that one might even speak of a Neubegrundung or re-foundation of the humanities.

However, Grosse claims that one branch of the humanities refuses to consider ethnology's data and approach. This branch is aesthetics, conceived as the theoretical study of the arts and their affective qualities. Aesthetics' refusal is surprising, says Grosse, for two reasons. First, the benefits of ethnology, specifically the "ethnological method," should be obvious to aesthetics particularly, he asserts. Second, the neglect is remarkable in that ethnology's importance for the problems of aesthetics has been clearly pointed out by others long before.

This acknowlegdment of predecessors leads Grosse to present a history of applying ethnological material and perspectives to questions in art theory or aesthetics. In this manner, Grosse historically grounds his enterprise for a contemporary audience he wishes to convince; he may even be said to create an intellectual ancestor gallery for his particular approach.

Grosse begins his discussion with a contemporary scholar whose work he assumes his 
readers to be familiar with. Hippolyte Taine, he notes, is sometimes credited for having introduced the ethnological method into aesthetics. But whatever the merits of this French scholar in rejuvenating the discipline, this is not a fame he can lay claim to. Taine may have applied the ethnological method, but he was not the first.

What does Grosse mean by the ethnological method? Today this label may evoke what anthropologists have come to call "participant observation." The term is used to designate the basic methodological prescription of ethnography that scholars live and work among a given people, learning their language and trying to perceive the world through their eyes. As a professional ethnographic or anthropological practice, however, participant observation, or fieldwork, is basically a twentieth-century phenomenon. Embedded research by cultural outsiders, at any rate, is not what Grosse has in mind when he talks of the ethnological method.

Grosse assigns two meanings to the ethnological method. First and foremost, it refers to the intercultural comparison of "peoples" or "nations," both in space and in time. In addition, the ethnological method pertains to studying phenomena within their contexts or environments, composed of interrelated ecological, economic, and sociocultural factors. Grosse's ethnological method, then, denotes the intercultural comparative study of contextualized data on a given subject. In order to understand Grosse's discussion of the ethnological method in Taine's work, one more observation needs to be made. As a legacy of twentieth-century practices, today we may tend to think of ethnology as the study of small-scale, traditionally oral cultures outside the West. Now for Grosse ethnology definitely includes the study of what for most of the twentieth century would be known as "primitive cultures." Indeed, these cultures he sees as the real "treasures of ethnology." However, the idea of ethnology being limited to these cultures was foreign to nineteenth-century scholars. Such a restricted conception emerged only in the early twentieth century, under the influence of colonialism especially.*4 Prior to that, ethnology included not only all extra-European cultures across space and time (whether small-scale or large-scale, literate or nonliterate) but European peoples or nations as well, both past and present. 
For Grosse, then, Taine deserves mention in the context of the ethnological method for two reasons. First, as prominently put forward in his Philosophie de l'art of $1865,{ }^{* 5}$ Taine formulated the "law" that every work of art is determined "by an aggregate made up of the general state of mind and the surrounding customs." Taine's law, with its Hegelian echoes, thus exemplifies in art theory the importance that ethnology attaches to sociocultural context. Second, Taine stressed that the laws governing artistic production can be uncovered only when one compares the art and culture of various periods and peoples. Taine's intercultural approach, too, makes his work ethnological, even though he limited his comparisons to European cultures-fifth-century BCE Greece, fifteenthcentury Italy, seventeenth-century Holland, etc.

These two dimensions of Taine's work - the contextual and the intercultural comparativeare to be applauded from a methodological point of view. But what Taine's admirers overlook, writes Grosse, is that he basically repeats what Jean Baptiste Dubos had already proposed in his Réflexions sur la poésie et sur la peinture of $1719 . * 6$ In this work, Dubos raised a question that according to Grosse constitutes one of the most important and difficult questions of aesthetics: Why does art flower among certain peoples and in certain periods, whereas in others it shows but a flimsy development? Dubos suggested that the peculiar character and achievements of each people depend on the quality of the air in their region. The presence or absence of talented artists among a given people he thus explained by reference to the local climate. Grosse admits that this is all "rather vague." But more important to him is the procedure by which this suggestion has been reached: Dubos applied the "ethnological comparative method."

Moreover, it is observed that Dubos adopted this method in a much more extensive manner than did Taine. Whereas the latter limited himself to the "civilized nations of Europe," his predecessor additionally considered not only Assyria, Persia, and Egypt, but India, China, Mexico, and Peru. Much as one may share Grosse's enthusiasm for such an early and wide-ranging intercultural approach in art theory, it needs mentioning that he gets slightly carried away. For a closer inspection of Dubos's work makes it clear that his references to the cultures mentioned are 
actually quite limited-Mexico and Peru, for example, each seem to be referred to only twice, China and Egypt a few times more, and Assyria is mentioned only once, in a nonartistic context (astronomy). Nonetheless, Grosse's favorable comment on Dubos's mention of these extraEuropean cultures is suggestive of the spatiotemporal scope he has in mind when talking about intercultural comparison.

Grosse then turns to Germany at the end of the eighteenth century to discuss a third and final predecessor, Johann Gottfried Herder. Grosse considers Herder the most diligent and eloquent advocate of "the idea of a comparative approach to the art and especially the poetry of all peoples." Grosse highlights Herder's emphasis on the diversity that becomes apparent when comparing the literary output of traditions from around the world. As in his discussions of Taine and Dubos, Grosse is especially interested in how Herder tried contextually to account for the intercultural differences in artistic expression, especially poetry. Referring to Herder's Briefe zur Beförderung der Humanität (Letters on the Advancement of Humanity), *7 he draws attention to the following factors: the actual language in which a literary work is written (including its sounds), local customs and traditions, and temperature and climate.

Grosse adds that Herder denounced looking down haughtily and ignorantly on the art forms of foreign peoples, and that he concluded by insisting that each artistic expression, literary or otherwise, be examined in the context of its time and place. These attitudes are very much in line with Gosse's own orientation. In fact, there appear to be many correspondences between both scholars' approaches to art and aesthetics beyond those hinted at by Grosse. They shared the view that aesthetic sensibility is a human universal (an idea not generally accepted in either Herder's or Grosse's days) and they both recognized cultural diversity in taste, seeking ways to explain it. They also shared an interest in the psychological and even physiological dimensions of aesthetic perception. More generally, Herder and Grosse alike resisted philosophical speculation and favored an empirical, bottom-up approach. In matters of art and aesthetics this stance involved close scrutiny of the artistic objects themselves. $* 8$ 
Despite his praise, Grosse feels compelled to conclude that, in the end, Herder was more concerned with the enjoyment of foreign poetry than its systematic study. Moreover, for all his attention to the art forms of various cultures, Herder is said to have undervalued the scholarly merit of what Grosse considers the most precious material that ethnology provides: the "aesthetic feelings and expressions" of the "lesser developed peoples." Nonetheless, Herder so clearly pointed the way to ethnology that Grosse feels it very difficult, if not impossible, to explain why later aestheticians have refused to take it.

It is true, writes Grosse, that in the eighteenth century the number of extra-European art objects at scholars' disposal was limited, and the information that accompanied them less than trustworthy. Still, foreign art works were no longer rarities in this period. Did not Dubos mention already in 1719 that Europe seemed full of Chinese and other East Asian objects? The problem is, Grosse suggests, that the works of art increasingly arriving in Europe in the eighteenth century were accorded not enough scholarly attention to be properly documented; not even their provenance was usually recorded. Travellers for their part provided only scant illustrations and descriptions of foreign art forms. If only aestheticians had shown more interest, it is argued, the lack of information about extra-European art works would not have become such a lasting impediment to their study.

Although Grosse has declared it almost impossible to explain why a Herderian turn towards ethnology was not forthcoming in art studies, at the end of his discussion of eighteenth-century developments he does briefly point to the intellectual influence of Herder's near-contemporaries Johann Winckelmann and Johann Wolfgang Goethe. It is suggested that Winckelmann and Goethe were instrumental in re-establishing the idea that only one type of art was deserving of the admiration and serious study of educated minds: the art of Western antiquity.

In the succeeding Romantic period a broadening of the horizon did take place, but the art of the "lesser developed peoples" was still not taken into account. Worse, according to Grosse, the Romantic spirit did not lend itself to serious scholarly work: "speculative fuddle" poisoned the minds of all kinds of scientist. But nowhere was this intoxication more lasting and damaging than in 
aesthetics, where scholars indulged in "mystical fantasies on the nature of art," basing their reflections solely on examples of European high art. No progress was made in this period and even the achievements of previous scholars were forgotten.

Here the empirically and interculturally minded Grosse meets his nemesis. The following quotation illustrates the vehemence with which he denounces the writings of Romantic aestheticians: "The speculative philosopher, from the heights of intellectual contemplation, where absolute beauty disclosed itself in a mystical glow, looked down with infinite contempt on the raw empiricists of the eighteenth century. Never have the words of aestheticians sounded so full as in this time, and never have they been so hollow. It was in all respects the most infertile period in the science of aesthetics, if in the face of these muddled and empty conceptual fantasies one can indeed speak of a science."*9 Grosse does not mention any Romantic aestheticians by name, but he may well have had in mind such scholars as Karl Wilhelm Schlegel, who "had demanded that the reflection on art must itself become aesthetic."*10 In Grosse's The Beginnings of Art, it is the subsequent writings on art and aesthetics of Hegel, Herbart, and their followers that are dismissed as speculative. Rightfully "sunk into a common oblivion," Grosse proclaims, their work "has to-day only a historical interest" (p. 3).

III

Things have indeed changed. Today, writes Grosse, speculation's hold on scholarship has been broken, first of all by the revival of the natural sciences, which he feels has had a revitalizing and liberating effect on the humanities, including aesthetics. Grosse was not alone among latenineteenth-century scholars to herald the achievements of the natural sciences, to promote the application of their methods to humanistic topics, and perhaps even to try to partake of their increased prestige. $* 11$

In the case of aesthetics, Grosse observes, the reorientation of the field is owed largely to such natural scientists as Hermann Helmholtz and Gustav Fechner. Special attention is paid to 
Fechner's Vorschule der Ästhetik (Elementary Aesthetics) of 1876, reporting on experimental studies in aesthetic evaluation.*12 Outside Germany, Grosse briefly mentions the efforts of the English biologist Grant Allen. He probably had in mind Allen's Physiological Aesthetics of $1877{ }^{*} 13$ This is an early study in Darwinian or evolutionary aesthetics, which "argued that aesthetic feelings have a physical basis, are the product of natural and sexual selection, and thus are not unique to humans."*14 In the context of these new developments Grosse mentions even Taine. Although not a natural scientist by training, Taine is claimed to have been the first to apply Darwin's theory of natural selection to art history, and thus to have been firmly rooted in the modern natural sciences.

Favoring a scientific approach, "modern aesthetics"-Grosse also calls it "empirical" or "positive" aesthetics_-provides a powerful antidote to the older "speculative aesthetics." In Fechner's famous phrase, it seeks to establish an aesthetics von unten (from below) in opposition to an aesthetics von oben (from above). Grosse admits that the problems addressed by modern aesthetics are modest compared to those that speculative aesthetics thinks to have cleared up. But then the questions empirical aesthetics poses are at least solvable. This brings us to a methodological viewpoint that fundamentally informs Grosse's work: Science must proceed from the simple to the complex; it cannot turn to more complicated issues if the relatively easy problems have not been solved first. As he will state in The Beginnings of Art, perhaps not coincidentally using an exact sciences analogy, "We have to learn the multiplication tables before we can solve the problems of higher mathematics" (p. 21).

However, Grosse finds even modern aesthetics wanting in that it, too, fails to consider the “treasures of ethnology." Grosse's criticism may be illustrated by his discussion of Fechner's Vorschule. This discussion also gives us the opportunity to broach a topic not yet addressed, namely Grosse's conception of what counts as empirical in aesthetics.

Fechner examined, among other things, the degree of visual pleasure afforded by various rectangular forms. For that purpose, he deployed one of three methods he proposed for experimental 
aesthetics, the method of use. This method examines works of art and other objects "on the assumption that the characteristics that are most commonly found in them will be those that win the most widespread approval in the society that has originated them."* 15 Fechner measured the widthto-length ratio of various rectangular objects of everyday use, such as picture frames, books, and tables. He concluded that the ratio of these objects' sides usually approximates that of the famous golden section, long held to have a special aesthetic value.

Grosse wonders, however, whether Fechner's conclusion can have the general validity it is suggested to have. For his examination is restricted to "the Western-European cultural sphere," its objects supposedly designed to cater to its peoples' taste. It would have sufficed for Fechner to measure the ratio of the sides of Japanese kakemono — vertical scroll paintings — to have learned that the golden section ratio does not apply in all cultures. But nowhere does Fechner suggest that experimental research take into account cultures outside Europe, and no one has performed a study that includes the aesthetic products of all the world's peoples. Yet such comparative studies are obviously needed, Grosse claims, in order to avoid the trap of basing a general theory of aesthetic feeling on but one or a few cases worldwide. The message is clear: even modern aesthetics is still in need of the contributions that ethnology's comparative method can provide.

The intercultural comparative study Grosse has in mind should proceed along the lines of Fechner's method of use, by examining objects from around the globe deemed artistic or aesthetic. The aesthetic feelings they are assumed to express - the local preferences they are held to embody - are then to be inferred from the objects' visual properties. It is these objects and their features that Grosse considers the empirical material of his comparative approach. He never considers the possibility of applying Fechner's other two methods, the method of choice and the method of production. These methods concentrate on people's conveyed preferences and the aesthetic principles that guide them in creating visually pleasing objects, respectively. The methods thus focus on different types of empirical data and involve different procedures for producing them. When decades after Grosse's proposals anthropologists of the fieldwork generation turned to 
examining aesthetic preference in extra-European cultures, they would proceed along the lines of these latter two methods, with an emphasis on people's verbally expressed visual preferences.*16

His critical historiography completed, and having aligned himself with the tenets of modern aesthetics, Grosse goes on to outline three crucial topics in art theory he feels can be properly dealt with only by using the ethnological method. These topics are the origins of art, and universalism and cultural relativism in art and aesthetics. Grosse's discussion of cultural differences also leads him to return to the topic of the environmental or contextual factors involved in determining not only artistic taste but talent.

IV

The historian James Clifford once talked of "the expansive world of the late nineteenth century, a time of opening horizons - geographical, cultural, scientific.”*17 This spirit of openness permeated young Ernst Grosse's cosmopolitan and optimistic views on future studies in aesthetics.

Rejuvenated by the sciences in method and approach, and with philosophical speculation discarded, all that aesthetics needed to do now was shed its eurocentric bias (as Dubos and Herder had already suggested long ago) by turning to ethnology. Ethnology would provide not only empirical data (as he saw it) on extra-European cultures in time and space, but a contextual and intercultural comparative perspective that held the promise of explanatory power. The global and interdisciplinary approach to art and aesthetics that Grosse dreamed of, however, was not to be in his lifetime. It is only now being attempted anew in contemporary terms by a growing number of scholars.

University of Leiden/University of Ghent

*1 Ernst Grosse, "Ethnologie und Aesthetik," Vierteljahrschrift für wissenschaftliche Philosophie 
15 (1891): 392-417; hereafter abbreviated "EA." Grosse returns to some of the essay's issues in Die Anfänge der Kunst (Freiburg: J. C. B. Mohr, 1894), a book that has been translated into several languages, including English: The Beginnings of Art, trans. Frederick Starr (New York: Appleton, 1897).

*2 See, for example, The Anthropology of Art: A Reader, ed. Howard Morphy and Morgan Perkins (London: Blackwell, 2006), especially the editors' introduction to "Foundations and Framing the Discipline," p. 35.

*3 See, for example, World Art Studies: Exploring Concepts and Approaches, ed. Kitty Zijlmans and Wilfried van Damme (Amsterdam: Valiz, 2008); Denis Dutton, The Art Instinct: Beauty, Pleasure, and Human Evolution (Oxford: Oxford University Press, 2009); Ben-Ami Scharfstein, Art Without Borders: A Philosophical Exploration of Art and Humanity (Chicago: The University of Chicago Press, 2009).

*4 Han F. Vermeulen, “Origins and Institutionalization of Ethnography and Ethnology in Europe and the USA, 1771-1845," in Fieldwork and Footnotes: Studies in the History of European Anthropology, ed. Han F. Vermeulen and Arturo Alvarez Roldán (London: Routledge, 1995), pp. 47-48.

*5 Hippolyte Taine, Philosophie de l'art (Paris: Ballière, 1865).

*6 Jean-Baptiste Dubos, Réflexions sur la poésie et sur la peinture (Paris: Pissot, 1719).

*7 Johann Gottfried Herder, Briefe zur Beförderung der Humanität, 2 vols., ed. Heinz Stolpe (Berlin: Aufbau, 1971) (work originally published between 1793 and 1797). 
*8 See, for example, Johann Gottfried Herder, Selected Writings on Aesthetics, trans. and ed. Gregory Moore (Princeton: Princeton University Press, 2006), pp. 197-203; Robert Edward Norton, Herder's Aesthetics and the Enlightenment (Ithaca: Cornell University Press, 1991), pp. 48, 109, $120,157-58$.

*9 "Mit einer unendlichen Verachtung blickte der speculative Aesthetiker von der Höhe der intellectuellen Anschauung, auf der sich ihm in mystischem Glanze die absolute Schönheit enthüllte, herab auf die rohen Empiriker des 18. Jahrhunderts. Niemals haben die Wörter der Aesthetiker so voll geklungen als in dieser Zeit und niemals sind sie so hohl gewesen. Er war in jeder Beziehung die unfruchtbarste Epoche, welche die ästhetische Wissenschaft erlebt hat, wenn man vor jenen verworrenen und leeren Begriffsdichtungen überhaupt noch von einer Wissenschaft reden kann" (“EA,” p. 396) (my translation).

*10 Kai Hammermeister, The German Aesthetic Tradition (New York: Cambridge University Press, 2002), p. 95.

*11 See Andrew Zimmerman, Anthropology and Antihumanism in Imperial Germany (Chicago: The University of Chicago Press, 2001).

*12 Gustav Fechner, Vorschule der Ästhetik (Leipzig: Breitkopf und Härtel, 1876). Hermann Helmholtz, Die Lehre der Tonemfindungen als physiologische Grundlage für die Theorie der Musik (Braunschweig: Fr. Viewegund und Sohn, 1863), English edition On the Sensations of Tone as a Physiological Basis for the Theory of Music, transl. Alexander Ellis (London: Longman, 1875).

*13 Grant Allen, Physiological Aesthetics (London: H.S. King, 1877). 
*14 Jonathan Smith, Charles Darwin and Victorian Visual Culture (Cambridge: Cambridge University Press, 2006), p. 162.

*15 Daniel E. Berlyne, Aesthetics and Psychobiology (New York: Appleton-Century-Crofts, 1971), p. 11 .

*16 See Wilfried van Damme, Beauty in Context: Towards an Anthropological Approach to Aesthetics (Leiden: Brill, 1996), especially chap. 6 on the methodology of empirical research in anthropological studies of aesthetic preference.

*17 James Clifford, Person and Myth: Maurice Leenhardt in the Melanesian World (Berkeley: University of California Press, 1982), p. 13. 